\footnotetext{
${ }^{1}$ Institute of Livestock Sciences, University of Natural Resources and Applied Life Sciences, Vienna, Austria

${ }^{2}$ Faculty of Animal Sciences and Agricultural Technology, Silpakorn University, Phetchaburi, Thailand

${ }^{3}$ Institute for Organic Farming and Biodiversity, Wels, Austria
}

\title{
Genetic characterization among some Austrian and Hungarian cattle breeds
}

\begin{abstract}
Microsatellite analysis was used to estimate genetic diversity and relationship of 180 individuals belonging to two native endangered Austrian cattle breeds, Carinthian Blond (CB) and Waldviertler Blond (WV), and Hungarian Grey (HU) from Hungary. Twenty-five markers were used, and a total of 213 alleles were detected, of which 54 alleles $(\sim 25 \%)$ were private alleles. Three breeds are clearly separated from each other with a correct assignment higher than $90 \%$. No bottlenecks were detected in any of the populations. A small amount of gene flow among the three populations occurred in the past. The closest genetic relationship is between Carinthian Blond and Waldviertler Blond (NEI et al.'s distance $\mathrm{D}_{\mathrm{A}},[1983]$; $\mathrm{D}_{\mathrm{A}}=0.11$ ). However, Carinthian Blond showed higher mean number of alleles per locus (6.76), number of private alleles (17) and expected heterozygosity (0.663) than Waldviertler Blond (6.04, 9 and 0.631 , respectively). The negative values of fixation index $F_{\text {IS }}(-0.018$ and -0.037 for $\mathrm{CB}$ and $\mathrm{WV}$, respectively) indicated that inbreeding is avoided, a sign for a successful conservation breeding program.
\end{abstract}

Keywords: genetic diversity, cattle, Carinthian Blond, Waldviertler Blond, Hungarian Grey, microsatellite, structure

\section{Zusammenfassung}

Titel der Arbeit: Genetische Charakterisierung einiger Österreichischer und Ungarischer Rinderrassen Die genetische Diversität von zwei gefährdeten Österreichischen Rinderrassen, dem Kärntner (CB) und dem Waldviertler Blondvieh (WV), sowie von der ungarischen Rasse Ungarisches Steppenrind (HU) wurde über Microsatelliten Loci untersucht. Pro Rasse wurden jeweils 60 Tiere für 25 Microsatelliten Loci typisiert. Insgesamt wurden 213 Allele entdeckt, wobei 54 (ca. 25\%) private Allele waren. Die drei Rassen konnten klar voneinander differenziert werden mit einer korrekten Zuordnung von Einzeltieren über $90 \%$. In keiner der Populationen konnte ein genetischer Flaschenhals nachgewiesen werden. Eine geringe Migrationsrate zwischen allen Populationen wurde ermittelt. Die engste genetische Beziehung besteht zwischen Waldviertler und Kärntner Blondvieh (NEI et al.'s distance $\mathrm{D}_{\mathrm{A}},[1983]$; $\mathrm{D}_{\mathrm{A}}=0.11$ ). Generell zeigte das Kärntner Blondvieh eine höhere durchschnittliche Anzahl von Allelen pro Locus (6,76), eine höhere Zahl privater Allele (17) und eine höhere erwartete Heterozygotie $(0,66)$ als das Waldviertler Blondvieh mit 6,04, 9 und 0,63. Die negativen Fixationsindex-Werte $\left(F_{\text {IS }}\right)$ in beiden Blondviehrassen können als Hinweis auf die Vermeidung von Inzucht und ein erfolgreiches Erhaltungszuchtprogramm interpretiert werden.

Schlüsselwörter: genetische Diversität, Rind, Kärntner Blondvieh, Waldviertler Blondvieh, Ungarisches Steppenrind, Microsatelliten, Struktur

\section{Introduction}

Carinthian Blond (CB) and Waldviertel Blond (WV) cattle used to be widespread in and around the Alpine region around 1900. During the following century the size of both populations was reduced drastically whereas Austrian Simmental and Brown Swiss became popular as high-yielding dual purposes breeds. At the present time, CB and WV populations are considered as highly endangered with about 700 breeding 
animals each. One special characteristic of both breeds is a very good meat quality. In addition CB also is known for it's as good fertility, good grazer and best mother qualities. Phenotype of $\mathrm{CB}$ is uniform silver white to light yellow with less pigmentation, pink muzzle, horn and claws in yellow while $\mathrm{WV}$ is blond to white, muzzle flesh-coloured, horn and claws in yellow-grey. CB and WV belong to the group of blond breeds. According to ÖNGENE (2007), CB aroused from a mixture between Slavonian and Franconian cattle from Germany while WV was composed of many breeds; the three major breeds were Celtic, Franconian cattle and Hungarian Grey (HU) a pure breed originated from Hungary with grey coat colour. The good characteristics of $\mathrm{HU}$ are high growth rate and lean meat content compared to Holstein Friesian (HOLLO et al., 2004). During the $19^{\text {th }}$ century, CB and WV were repeatedly crossed with Blond Franconian cattle.

The conservation breeding programs for WV and CB were established in 1995. However, phenotypic conservation criteria are not considered to be sufficient to maintain original breeds' characteristics. Additional sources of information like pedigree and molecular genetic information might be used in conservation breeding programs. Therefore the goal of this study was to investigate differences and similarities of closely related populations based on microsatellite marker information, to assess the genetic diversity, breed relationships, gene flow, population structure and possible bottlenecks of $\mathrm{CB}, \mathrm{WV}$ and $\mathrm{HU}$ populations.

\section{Materials and methods}

\section{Animals and microsatellite markers}

Blood from 60 unrelated animals per breed was sampled including CB, WV and HU. All animals were genotyped for 29 microsatellite markers recommended for genetic diversity studies in cattle by FAO (http://www.projects.roslin.ac.uk/cdiv/markers.html). Null allele frequencies were estimated for each locus using EM algorithm (DEMPSTER et al., 1977) for 10,000 replications by FREENA. We excluded 4 loci HAUT27 (15.2\%), HEL13 (18.4\%), ILSTS005 (11.3\%) and INRA35 (36.6\%) from further calculations because of estimated null allele frequencies above $10 \%$.

\section{Data analysis}

Each population was tested for Hardy-Weinberg equilibrium using GENEPOP v3.4. A sequential Bonferroni correction $(\alpha=0.05)$ was used to correct for multiple comparisons. Observed and expected heterozygosity across breeds were estimated by GENETIX v4.05 and were tested by paired $t$ tests (SAS 9.1.3 for Windows) to determine if there were significant differences between them within each population, at each locus and overall. Additionally the mean number of alleles across loci was estimated by EXCEL MICROSATELLITE TOOLKIT. Numbers of private alleles were estimated by CONVERT. Fixation coefficients $\left(F_{\mathrm{IS}}, F_{\mathrm{IT}}\right.$ and $\left.F_{\mathrm{ST}}\right)$ were calculated using POPGEN v1.32. The number of effective migrants per generation $(\mathrm{Nm})$ was based on $F_{\mathrm{ST}}$ estimates (WEIR and COCKERHAM, 1984) and was calculated as $N m=\left(1-F_{\mathrm{ST}}\right) / 4 \cdot F_{\mathrm{ST}}$ (WRIGHT, 1969) by GENETIX.

Genetic relationships among breeds and individuals were derived using NEI et al.'s distance $\mathrm{D}_{\mathrm{A}}(1983)$. $\mathrm{D}_{\mathrm{A}}$ has been shown to be appropriate for phylogenetic studies of both infinite-allele model (IAM) and stepwise mutation model (SMM) and in obtaining the correct topology $\left(\mathrm{P}_{\mathrm{C}}\right)$ (TAKEZAKI and NEI, 1996). Distance matrices 
were calculated using POPULATION v1.2.30 beta2. Robustness of the UPGMA of the population tree was tested by 10,000 bootstraps on loci and the cladogram was drawn with PHYLODRAW. The radial tree of individuals was drawn with HYPERTREE. However, the concept behind a phylogenetic tree was that populations can separate into several groups which subsequently no migration between populations (OLDENBROEK, 1999). Therefore we applied a principal component analysis (PCA) conducted by PCA-GEN to visualize genetic differentiation among individuals of cattle breeds. The genotypes of each individual were ordinated in a multidimensional space. The statistical significance associated with each axis was calculated over 10,000 randomizations.

STRUCTURE v2.2 was applied to estimate the number of genetic subpopulations or clusters $(K)$. Ten independent runs of $K=1-7$ with 1,000,000 Markov chain Monte Carlo (MCMC) iterations and a burn-in period of 1,000,000 were performed, using the admixture model with correlated allele frequencies and no informative priors about individual membership. The program DISTRUCT written by ROSENBERG (2004) was used to visualizing these estimated membership coefficients. Subpopulations were presented as colours, and individuals were depicted as bars partitioned into coloured segments that correspond to membership coefficients in the subgroups. Assignment of individual cattle to their most likely breed was performed by GENECLASS2 using Baysian method (RANNALA and MOUNTAIN, 1997) with 10,000 simulated individuals.

The bottlenecks were assessed by using two methods provided by the software package BOTTLENECK v1.2.02. The first method was the heterozygosity excess method described by CORNUET and LUIKART (1996). This method exploits the fact that allelic diversity is reduced faster than heterozygosity during a bottleneck, because rare alleles are lost rapidly and have little effect on heterozygosity, thus producing a transient excess in heterozygosity relative to that expected in a population of constant size with the same number of alleles. Two statistical tests have been proposed to evaluate such differences. We applied standardized differences test (T2 values) and Wilcoxon signed-rank test (probabilities-one tail for $\mathrm{H}$ excess) to estimate the probability of heterozygosity excess. The second method was a graphical examination of allele frequencies described by LUIKART et al. (1998). In a population of constant size, many alleles should be rare. In contrast, a recently bottlenecked population is expected to show fewer rare alleles, as they are lost most quickly. A histogram of the proportion of alleles in a dataset at different frequencies should thus reveal a deficit of rare alleles, or a mode shift. We carried out 10,000 replicates and assumed that all loci follow the SMM or two-phase mutation model (TPM) appropriate for microsatellite markers. We used the TPM with $95 \%$ singlestep mutations and 5\% multistep mutations, as recommended by PIRY et al. (1999).

\section{Results}

\section{Test for Hard-Weinberg equilibrium}

INRA32 in HU showed a significant heterozygote deficit $(\mathrm{P}<0.01)$. Further two loci in WV, INRA23 and INRA32, showed a significant heterozygote excess $(\mathrm{P}<0.05)$. After applying the sequential Bonferroni correction, no departure from HWE was observed across samples and loci. 


\section{Genetic diversity among loci}

In total, 213 alleles were observed at the 25 loci (Table 1). All 25 loci were polymorphic in the 3 breeds. The number of alleles per locus ranged from 4 (INRA005) to 14 (TGLA53) with means of $8.52 \pm 2.52$. The number of private alleles was highest in TGLA122 (7) and 3 loci had no private allele. Levels of expected $\left(H_{\mathrm{e}}\right)$ and observed $\left(H_{\mathrm{o}}\right)$ heterozygosity were higher than 0.500 among loci $\left(H_{e}=0.518\right.$ $0.864)$ except ETH10 locus $\left(H_{e}=0.287\right)$. There were significant difference between $H_{\mathrm{e}}$ and $H_{\mathrm{o}}$ at 2 loci, TGLA126 ( $\left.\mathrm{p}=0.001\right)$ with $H_{\mathrm{o}}>H_{\mathrm{e}}$ and ETH152 ( $\left.=0.022\right)$ with $H_{\mathrm{o}}<H_{\mathrm{e}}$. The exact test for population differentiation based on allele frequency variation showed that all breeds investigated were significantly different from each other $(\mathrm{P}<0.001)$.

$F_{\mathrm{ST}}$ values indicated that around $6 \%$ of the total genetic variation can be explained by breed differences, the remaining $94 \%$ corresponding to differences among individuals (Table 1).

Table 1

Number of alleles, number of private allele, expected heterozygosity $\left(H_{\mathrm{e}}\right)$, observed heterozygosity $\left(H_{\mathrm{o}}\right)$ and fixation indices $\left(F_{\mathrm{IS}}, F_{\mathrm{IT}}\right.$ and $\left.F_{\mathrm{ST}}\right)$ according to WEIR and COCKERHAM (1984) for 25 microsatellite loci

(Anzahl von Allelen, privaten Allelen, erwartete Heterozygotie $\left[H_{\mathrm{e}}\right]$, beobachtete Heterozygotie $\left[H_{\mathrm{o}}\right]$ und Fixationsindices $\left[F_{\mathrm{IS}}, F_{\mathrm{IT}}\right.$ und $F_{\mathrm{ST}}$ ] nach WEIR und COCKERHAM [1984] für 25 Microsatelliten Loci)

\begin{tabular}{lrrrrrrr}
\hline Loci & $\begin{array}{c}\text { Number of } \\
\text { alleles }\end{array}$ & Private allele & \multicolumn{1}{c}{$H_{\mathrm{e}}$} & $H_{\mathrm{o}}$ & \multicolumn{1}{c}{$F_{\mathrm{IS}}$} & \multicolumn{1}{c}{$F_{\mathrm{IT}}$} & $F_{\mathrm{ST}}$ \\
\hline BM1818 & 7 & 1 & 0.631 & 0.600 & 0.0014 & 0.0468 & 0.0455 \\
BM1824 & 5 & - & 0.738 & 0.706 & -0.0435 & 0.0407 & 0.0807 \\
BM2113 & 8 & 2 & 0.797 & 0.722 & -0.0336 & 0.0910 & 0.1206 \\
CSRM60 & 9 & 3 & 0.725 & 0.667 & -0.0576 & 0.0775 & 0.1277 \\
CSSM66 & 10 & 1 & 0.790 & 0.772 & -0.0117 & 0.0192 & 0.0306 \\
ETH10 & 7 & 2 & 0.287 & 0.289 & -0.0612 & -0.0101 & 0.0481 \\
ETH152 & 6 & 1 & 0.680 & 0.570 & 0.0674 & 0.1592 & 0.0984 \\
ETH185 & 13 & 6 & 0.748 & 0.687 & 0.0192 & 0.0790 & 0.0610 \\
ETH225 & 5 & - & 0.665 & 0.667 & -0.0300 & -0.0050 & 0.0243 \\
ETH3 & 7 & 2 & 0.615 & 0.583 & 0.0062 & 0.0484 & 0.0424 \\
HEL1 & 9 & 1 & 0.753 & 0.669 & -0.0365 & 0.1123 & 0.1436 \\
HEL5 & 8 & 4 & 0.732 & 0.686 & 0.0126 & 0.0594 & 0.0474 \\
HEL9 & 10 & 3 & 0.732 & 0.706 & -0.0476 & 0.0339 & 0.0777 \\
ILSTS006 & 9 & 1 & 0.668 & 0.607 & -0.0289 & 0.0917 & 0.1172 \\
INRA005 & 4 & 1 & 0.800 & 0.833 & -0.0906 & -0.0444 & 0.0424 \\
INRA23 & 10 & 3 & 0.636 & 0.583 & -0.0261 & 0.0805 & 0.1039 \\
INRA32 & 8 & 5 & 0.518 & 0.520 & -0.0243 & -0.0064 & 0.0175 \\
INRA37 & 10 & 1 & 0.672 & 0.661 & -0.0291 & 0.0151 & 0.0429 \\
INRA63 & 7 & 2 & 0.804 & 0.789 & -0.0136 & 0.0156 & 0.0288 \\
MM12 & 11 & 1 & 0.671 & 0.650 & -0.0026 & 0.0282 & 0.0307 \\
SPS115 & 7 & 7 & 0.701 & 0.644 & 0.0686 & 0.0783 & 0.0103 \\
TGLA122 & 13 & 3 & 0.717 & 0.700 & -0.0487 & 0.0211 & 0.0666 \\
TGLA126 & 7 & - & 0.843 & 0.809 & -0.0004 & 0.0377 & 0.0382 \\
TGLA227 & 9 & 0.864 & 0.822 & 0.0039 & 0.0456 & 0.0418 \\
TGLA53 & 14 & 0.698 & 0.662 & -0.0158 & 0.0481 & 0.0630 \\
All & 213 & & & & & \\
\hline
\end{tabular}

Genetic diversity among breeds

The expected heterozygosity among the 3 breeds was highest for HU and lowest for WV while the observed heterzygosity was highest for CB and also lowest for WV (Table 2). However, a significant difference between expected and observed heterozygosity was detected in WV $(\mathrm{p}=0.03)$ only. $F_{\text {IS }}$ values were negative and significant different from 0 in $\mathrm{CB}$ and $\mathrm{WV}$. The mean number of alleles per locus was highest in $\mathrm{CB}(6.76)$ and also 
lowest in WV (6.04). The total number of private alleles and the number of private alleles with a frequency higher than $0.01 \%$ were 17,9 and 28 alleles and 10, 4 and 28 alleles for $\mathrm{CB}, \mathrm{WV}$ and $\mathrm{HU}$, respectively.

Table 2

Expected heterozygosity $\left(H_{\mathrm{e}}\right)$ and observed heterozygosity $\left(H_{\mathrm{o}}\right), F_{\mathrm{IS}}$, mean number of alleles (MNA), allelic richness and number of private alleles per breed

(Erwartete Heterozygotie $\left[H_{\mathrm{e}}\right]$ und beobachtete Heterozygotie $\left[H_{\mathrm{o}}\right], F_{\mathrm{IS}}$, durchschnittliche Anzahl von Allelen, Allelanreicherung und Anzahl privater Allele pro Rasse)

\begin{tabular}{lccccrr}
\hline Population & $H_{\mathrm{e}}(\mathrm{SD})$ & $H_{\mathrm{o}}(\mathrm{SD})$ & $F_{\mathrm{IS}}$ & MNA (SD) & $\begin{array}{r}\text { Number of Private alleles } \\
\text { Total }\end{array}$ & $\begin{array}{c}\text { Frequency } \geq 0.1 \\
\text { CB }\end{array}$ \\
\hline WV & $0.663(0.030)$ & $0.675(0.012)$ & $-0.0180^{2}$ & $6.76(2.11)$ & 17 & 10 \\
HU & $0.631^{1}(0.027)$ & $0.655(0.012)$ & $-0.0368^{2}$ & $6.04(1.79)$ & 9 & 4 \\
All & $0.679(0.024)$ & $0.658(0.012)$ & 0.0308 & $6.52(1.81)$ & 27 & 24 \\
\hline
\end{tabular}

1 = significant difference from $H_{\mathrm{o}}(\mathrm{P}=0.03)$ by pair t-test; 2 = significant difference from $0(\mathrm{P}<0.02)$ by pair t-test

\section{Genetic structure and gene flow}

Population differentiation among breeds was presented by pairwise $F_{\mathrm{ST}}$ coefficients (Table 3). $F_{\mathrm{ST}}$ coefficients ranged from 0.06 (between $\mathrm{CB}$ and WV) to 0.11 (between $\mathrm{WV}$ and $\mathrm{HU}$ ). Thus, 6 to $11 \%$ of the microsatellite variability was explained by between breeds variability while the remaining variability was explained by the variation within breeds. Gene flow between breeds was shown by estimating the number of migrants per generation ( $\mathrm{Nm}$, where $N$ was the total effective number of cattle and $m$ was the migration rate). The highest migration rate was estimated between $\mathrm{CB}$ and $\mathrm{WV}$ (3.60) and the lowest migration rate between WV and HU (2.08).

Table 3

Population differentiation among breeds based on 25 microsatellite loci presented by $F_{\mathrm{ST}}{ }^{1}$ (above diagonal) and gene flow ${ }^{2}(\mathrm{Nm})$ (below diagonal) (Differenzierung der Rassen basierend auf 25 Microsatelliten Loci, dargestellt durch $F_{\mathrm{ST}}{ }^{1}$ [oberhalb der Diagonale] und durch den Genfluss ${ }^{2}(\mathrm{Nm})$ [unterhalb der Diagonale])

\begin{tabular}{llll}
\hline & CB & WV & HU \\
\hline CB & - & 0.0649 & 0.0685 \\
WV & 3.60 & - & 0.1073 \\
HU & 3.40 & 2.08 & - \\
\hline
\end{tabular}

$1=F_{\mathrm{ST}}$ estimates were calculated as described by WEIR and COCKERHAM (1984); $2=$ The number of effective migrants per generation $(\mathrm{Nm})$ or gene flow were estimated using formula, $N m=\left(1-F_{\mathrm{ST}}\right) / 4 \cdot F_{\mathrm{ST}}$, derived by WRIGHT (1969)

\section{Breed relationships}

Table 4 shows the values of $\mathrm{D}_{\mathrm{A}}$ (NEI, 1983) genetic distances assessed among all breeds. Figure 1 presented a cladogram depicting the genetic relationships between breeds. HU population split away from the two blond breeds. Generally the high bootstrapping values indicated a very stable phylogeny. Just two animals from WV were found in $\mathrm{CB}$ cluster, two animals from $\mathrm{CB}$ in $\mathrm{HU}$ cluster, and one animal from $\mathrm{HU}$ and two animals from $\mathrm{CB}$ in WV cluster (Figure 2). The result of PCA is shown in Figure 3. Individual scores were plotted onto the two principle axes. The principle component 1 extracted $9 \%(\mathrm{p}=0.74)$ and principle component 2 extracted $6 \%$ $(\mathrm{p}=0.21)$ of the total variance among individuals. The plotting showed a clear separation between HU (placed on the right side of the plot) and WV (placed on the left side of the plot) on principle component 1. CB separated from HU and WV on principle component 2 with some individuals overlapping between populations and some individuals are misplaced (showed in circles and squares). 


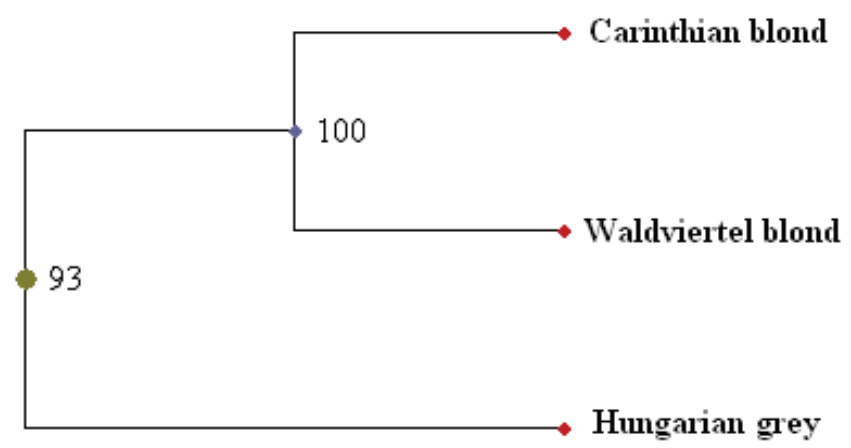

Fig. 1: The UPGMA cladogram of 3 breeds based on NEI et al.'s, $D_{A}$ (1983), 10,000 bootstraps on loci (UPGMA Kladogramm von 3 Rassen basierend auf NEI et al.'s $D_{A}$ (1983), 10.000 bootstraps über Loci)

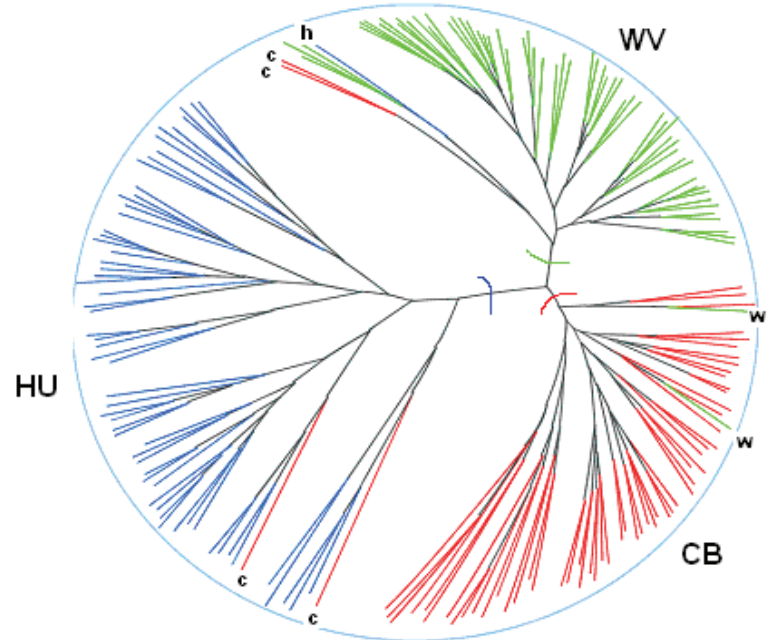

Fig. 2: Radial tree for 180 individuals based on NEI et al.'s $\mathrm{D}_{\mathrm{A}}$ (1983), Neighbor joining method. Individuals from a particular breed grouped into a cluster are indicated as $\mathrm{c}, \mathrm{h}$ and $\mathrm{w}$ were misclassified individuals coming from CB, HU and WV populations, respectively (Radial-Baum für 180 Individuen basierend auf NEI et al.'s $D_{A}$ (1983), Neighbor-Joining-Verfahren. Individuen einer bestimmten Rasse, die in einem Cluster gruppiert wurden, aber von der Rasse $\mathrm{CB}, \mathrm{HU}$ and $\mathrm{WV}$ stammen, werden jeweils durch $\mathrm{c}, \mathrm{h}$ und $\mathrm{w}$ gekennzeichnet)

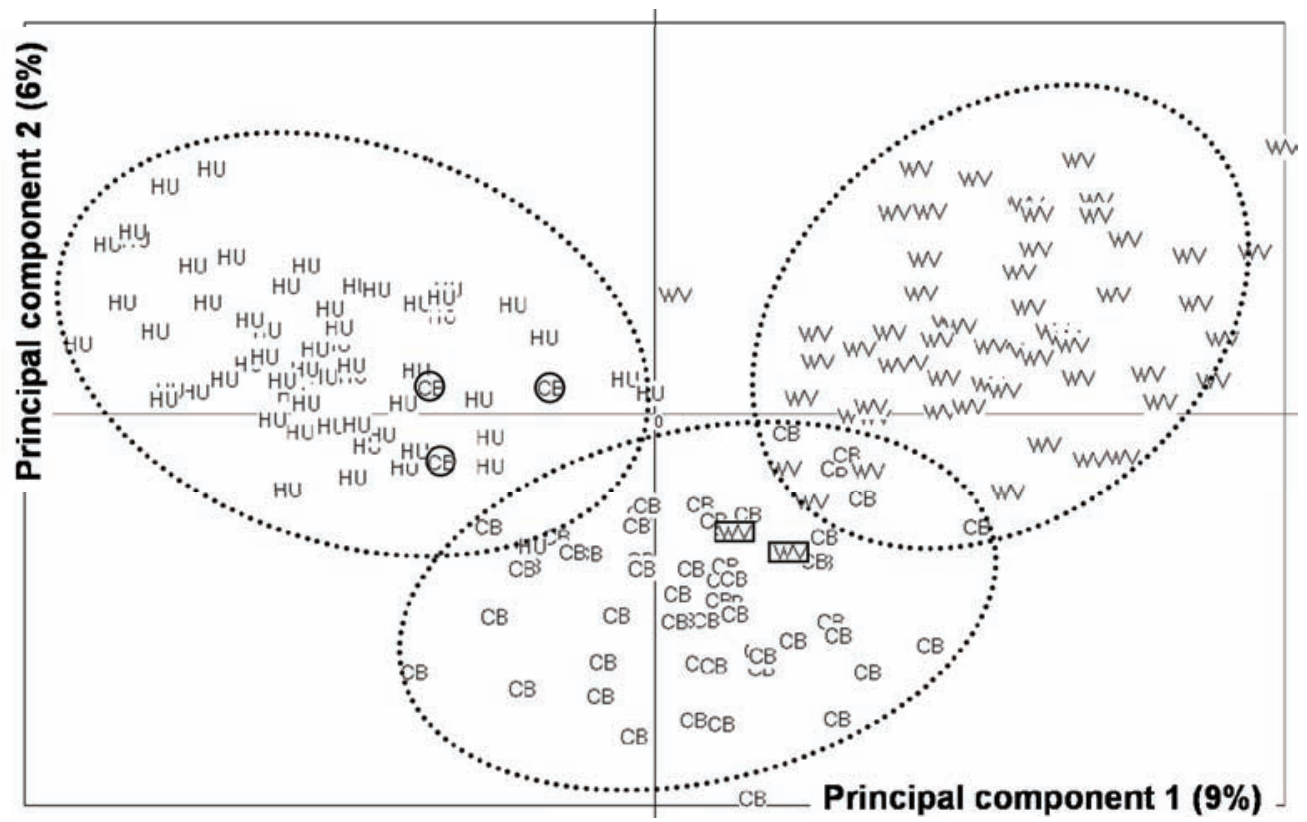

Fig. 3: PCA plot of allele frequencies based on individual genotypic data from all populations. Misclassified individuals were indicated by circles ( $\mathrm{CB}$ in $\mathrm{HU}$ ) and squares (WV in $\mathrm{CB}$ ). (PCA Plot der Allelfrequenzen basierend auf individuellen Genotypen der untersuchten Populationen. Falsch klassifizierte Tiere werden durch Kreise [CB in HU] und Quadrate [WV in CB] gekennzeichnet.) 
Table 4

Distance matrix based on NEI et al.'s $D_{A}$ (1983) between breeds

(Distanzmatrix zwischen den Rassen auf der Basis von NEI et al.'s $D_{A}$ [1983])

\begin{tabular}{lll}
\hline Population & CB & WV \\
\hline WV & 0.1087 & - \\
HU & 0.1381 & 0.1765 \\
\hline
\end{tabular}

\section{Population structure and admixture level}

Clustering results of breeds obtained by STRUCTURE applying $K=2$ to $K=7$ are shown in Figure 4. At $K=2$, the three breeds split into 2 groups, one containing the two Austrian blond breeds while HU was separated. At $K=3$, the three breeds were separated into three groups with the proportions of membership of each pre-defined population of $94.2 \%, 92.7 \%$ and $97.1 \%$ for $\mathrm{CB}, \mathrm{WV}$ and $\mathrm{HU}$, respectively. Misclassified individuals were distributed among all breeds. Misclassification proportions varied from $1.3 \%$ to $5.9 \%$. HU was the most correctly classified breed, and $\mathrm{WV}$ was the most misclassified. At $K=4, \mathrm{CB}$ split into 2 groups, at $K=5$, also WV split into 2 groups. However, the genetic structure of HU population seemed to be highly uniform and never separated at any $K$ up to $K=7$. The highest value of $\mathrm{Ln}$ $\operatorname{Pr}(\mathrm{G} \mid \mathrm{K})$ with lowest variation between runs was obtained for $K=3(-12138.2)$ as show in Figure 5. These three inferred populations would correspond to the ancestral populations from which our current breeds were derived.

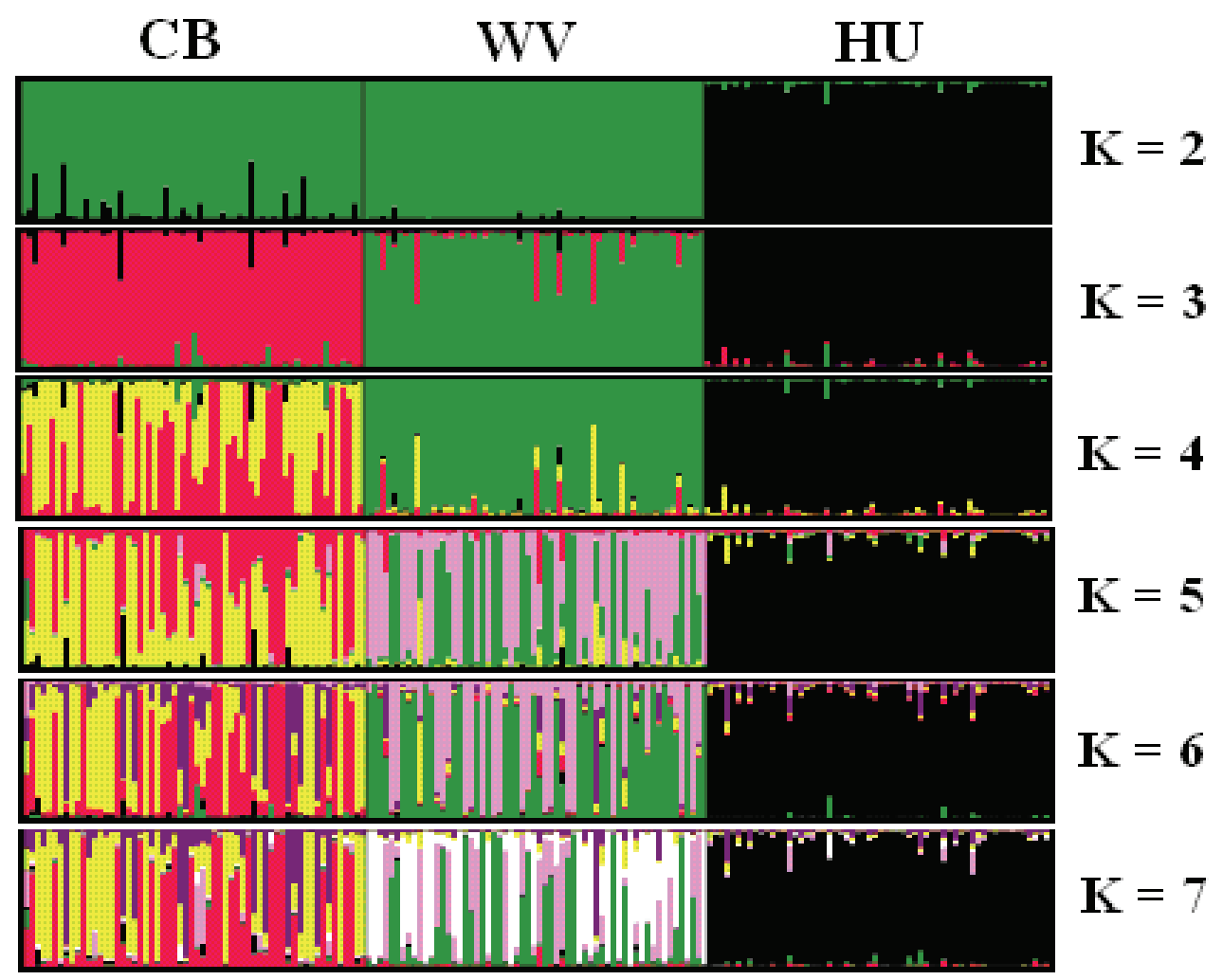

Fig. 4: Graphical presentation of the population structure. Each population is separated by a vertical line, which was sectioned into $K$ coloured segments that represent the proportion of membership of each predefined population in $K$ clusters. The populations are labelled above the figure. (Grafische Darstellung der Populationsstruktur. Die Populationen sind durch vertikale Linien getrennt, welche in $K$ gefärbte Abschnitte aufgeteilt sind, die dem Anteil der Zugehörigkeit zur jeweiligen vordefinierten Population in $K$ Clustern entsprechen. Die Populationen sind oberhalb der Grafik angeführt) 


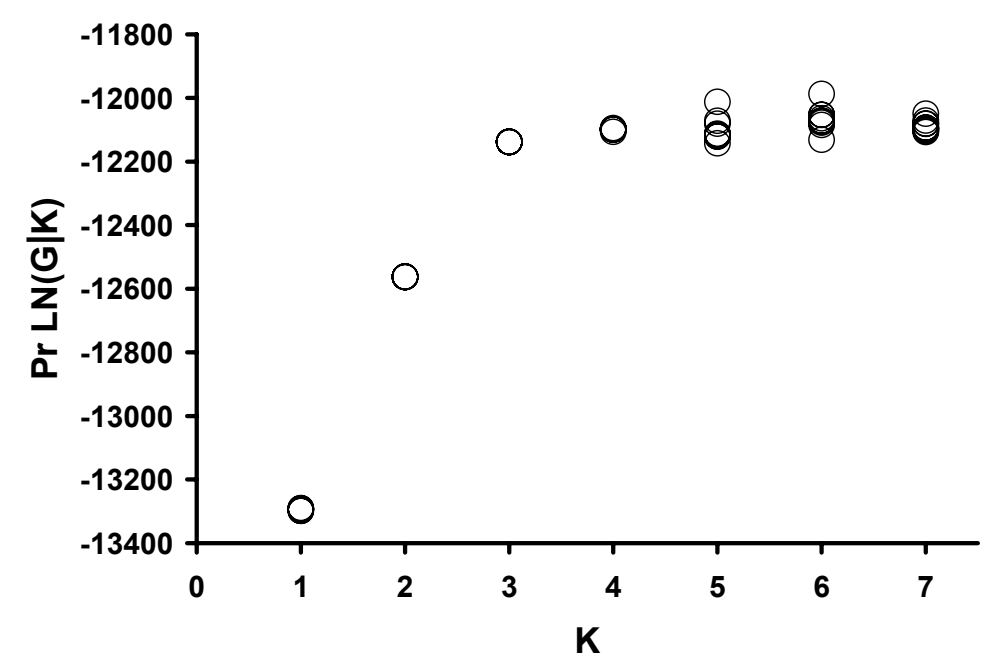

Fig. 5: $\operatorname{Ln} \operatorname{Pr}(\mathrm{G} \mid \mathrm{K})$ values presented as a function of the number of clusters (each $K=10$ runs), burn-in period and collected data for 1,000,000 iterations $(\operatorname{Ln} \operatorname{Pr}(\mathrm{G} \mid \mathrm{K})$ (Werte, dargestellt als eine Funktion der Anzahl an Clustern [jedes K=10 Runs], Burn-in-Periode und erfassten Daten von 1.000.000 Iterationen)

\section{Breed Assignment}

The direct method described by RANNALA and MOUNTAIN (1997) allowed the correct assignment of $97.2 \%$ of individuals to their breed of origin. However, there were 4 individuals from WV that could not be assigned correctly and one migrant was detected $(\mathrm{P}<0.01)$.

\section{Bottleneck Detection}

We used Sign Standardized differences (T2) and Wilcoxon sign rank tests to characterize bottlenecks in three populations (Table 5). Using the Wilcoxon rank test, the p-values were greater than 0.9 for all populations and both models TPM and SMM. Results from both tests indicated that, due to mutation-drift equilibrium, a recent genetic bottleneck did not occur in CB, WV and HU. The Mode-shift indicator test was also utilized as a second method to detect potential bottlenecks, as the non bottleneck populations that were near mutation-drift equilibrium were expected to have a large proportion of alleles with low frequency. A graphical representation utilizing allelic class and proportion of alleles show a normal L-shaped distribution (data not shown here) in all populations. This distribution clearly reinforced the result that the three populations have not experienced a recent bottleneck.

\section{Table 5}

T2 values for standardized differences test and one tailed probabilities for Heterozygote excess for Wilcoxon test in three populations obtained from 25 microsatellites of TPM and SMM models for bottleneck test (T2 Werte für standardisierten Differenztest und einseitige Wahrscheinlichkeiten für Heterozygoten Exzess für den Wilcoxon Test in drei Populationen, basierend auf 25 Mikrosatelliten von TPM und SMM Modellen für den Flaschenhalstest)

\begin{tabular}{lccc}
\hline Model & Pop & $\begin{array}{c}\text { Standardized differences test } \\
\text { (T2 values and P-value) }\end{array}$ & $\begin{array}{c}\text { Wilcoxon test } \\
\text { (probabilities-one tail for H excess) }\end{array}$ \\
\hline \multirow{2}{*}{ TPM* $^{*}$} & CB & $-3.825(0.00007)$ & 0.99518 \\
& WV & $-3.619(0.00015)$ & 0.98626 \\
& HU & $-2.509(0.00606)$ & 0.94634 \\
SMM & CB & $-5.780(0.00000)$ & 0.99979 \\
& WV & $-5.369(0.00000)$ & 0.99875 \\
& HU & $-4.207(0.00001)$ & 0.99518 \\
\hline
\end{tabular}

*parameter in TPM, $95 \%$ single-step mutation, $5 \%$ multiple-step mutation and variance among multiple steps $=12$ 


\section{Discussion}

The expected heterozygosity among and within breed were high indicating that all 25 markers were valuable to assess the genetic diversity in our populations. HU shows the highest level of genetic diversity with regard to expected heterozygosity. Conversely, CB shows the highest level of genetic diversity if assessed by observed heterozygosity and mean number of alleles per locus. However, WV shows clearly the lowest genetic diversity regarding expected and observed heterozygosity as well as number of alleles per locus.

The large number of private alleles in HU may reflect its long distance to the other breeds while the small number of private alleles in WV may reflect its short distance to the other breeds investigated. Moreover, the frequencies of private alleles were lower than $10 \%$ in all populations except 184 bps allele at INRA32 in WV $(>36.67 \%)$ that might be a unique characteristic of WV population. A high frequency of a private allele could also reflect that some individuals are closely related or cattle were sampled intensively in a region (KALINOWSKI, 2004), which should not be the case because a representative sample of individuals as unrelated as possible was taken for this study.

The negative values of $F_{\text {IS }}$ were small but significantly different from 0 which indicates outcrossing exists in CB and WV (CHESSER, 1991) or mating of close relatives is avoided a sign for a successful conservation program. Another reason for the negative values of these statistics could be gene flow from other populations (JORDANA et al., 1999). Conversely, positive $F_{\text {IS }}$ was detected in HU but not significantly different from 0 which indicate that no severe inbreeding occurs in the HU population.

The genetic distances $\left(F_{\mathrm{ST}}\right)$ measured between all pairs of breeds can be considered $(0.063)$ to be moderate (HARTL and CLARK, 1997) and smaller than that reported for 20 Northern European breeds using 10 microsatellites $\left(F_{\mathrm{ST}}=0.107\right.$; KATANEN et al., $2000)$ and 7 other European breeds using 20 microsatellites $\left(F_{\mathrm{ST}}=0.112\right.$; MACHUGH et al., 1998) but larger than 4 native Spanish cattle breeds employing 11 microsatellites $\left(F_{\mathrm{ST}}=0.041\right.$; RENDO et al., 2004). However, it was similar to the value obtained among 18 local cattle breeds from Spain, Portugal and France, using 16 microsatellites $\left(F_{\mathrm{ST}}=0.07\right.$; CANON et al., 2001), 7 French breeds with 23 microsatellites $\left(F_{\mathrm{ST}}=0.08\right.$; MAUDET et al., 2002), and 3 native Italian cattle breed with 21 microsatellites loci $\left(F_{\mathrm{ST}}=0.06\right.$; MOIOLI et al., 2004).

The NEI's genetic distance matrix showed that HU was most divergent from the others $(0.18$ in relation to $\mathrm{WV}$ and 0.14 in relation to $\mathrm{CB}$ ). Genetic distance was lowest $\left(\mathrm{D}_{\mathrm{A}}=0.11\right)$ between $\mathrm{CB}$ and $\mathrm{WV}$. We expected HU should be closer to WV than CB because WV originated from HU according to ÖNGENE (2007). However, genetic distances showed that HU was closer to $\mathrm{CB}$ than WV. The effect of gene flow between HU and CB (3.4) was high enough to attenuate the genetic differentiation between populations in an infinite island model (TREXLER, 1988).

As expected the differentiation between $\mathrm{CB}$ and WV is lowest and the migration rate is highest indicating the existence of gene flow between the Austrian Blond breeds. However, low levels of gene flow among breeds are most likely due to the clear separation into three clusters. This is also in agreement with the results shown in the PCA plot showing some overlap between CB-WV and CB-HU while WV-HU is totally separated. 
Genetic differentiation among individuals was fully recognized by PCA and Neighbor joining clustering procedures which, without using prior population information, split the individuals into 3 clusters corresponding to the three breeds with some individuals misclassified in both methods. Most of the misclassified individuals in PCA are corresponding to the misclassified individuals in Neighbor joining method.

However, the program structure showed at $K=4, \mathrm{CB}$ split into 2 groups and at $K=5$, WV split into 2 groups while HU never split at any $K(K \leq 7)$. It can be indicated that genetic structure of WV was more consistent than $\mathrm{CB}$, while the genetic structure of $\mathrm{HU}$ was highly uniform. Moreover, this indicated that $\mathrm{CB}$ and WV had experience crossing with other breeds before a strict conservation program was established. Further investigation is needed to reveal which breeds were involved.

In conclusion, the present investigation confirms that all 3 breeds are clearly separated from each other, while Carinthian Blond and Waldviertel Blond show the closest relationship. It was detected that the genetic structure of Carinthian Blond was less homogeneous than Waldviertel Blond indicating the presence of outcrossing with other breeds. Therefore it still needs further investigations. Furthermore, even phenotypically very similar breeds turned out to be genetically clearly distinct. In total, the results of this study confirmed that the current conservation breeding program works well because mating of related animals is avoided and populations of Waldviertel Blond and Carinthian Blond are kept clearly separately.

\section{Acknowledgements}

This research project was financially supported by ÖNGENE and the Royal Thai government. We are grateful to Dr.Laszlo Radnoczi from the County Agricultural Office in Budapest for providing 60 samples for Hungarian Grey.

\section{BOTTLENECK:}

\section{References}

A program for detecting recent effective population size reductions from allele data frequencies. Available at http://www.montpellier.inra.fr/URLB/bottleneck/bottleneck.html (1999)

CANON, J.; ALEXANDRINO, P.; BESSA, I.; CARLEOS, C.; CARRETERO, Y.; DUNNER, S.; FERRAN, N.; GARCIA, D.; JORDANA, J.; LALOE, D.; PEREIRA, A.; SANCHEZ, A.; MOAZAMI-GOUDARZI,K.: Genetic diversity measures of local European beef cattle breeds for conservation purposes. Genet. Sel. Evol. 33 (2001), 1-22

CHESSER; R.K.: Gene diversity and female philopatry. Genetics 127 (1991), 437-447

CORNUET, J.M.; LUIKART, G.L.: Description and power analysis of two tests for detecting recent population bottlenecks from allele frequency data. Genetics 144 (1996), 2001-2014

DEMPSTER, A.P.; LAIRD, N.M.; RUBIN, D.B.: Maximum likelihood from incomplete data via the EM algorithm. J. R. Stat. Soc. B. 39 (1977), 1-38 HARTL, D.L.; CLARK, A.G.: Principle of population genetics. Sinauer Associates, $3^{\text {rd }}$ edition, Sunderland, Massachussetts (1997)

HOLLO, G.; NÜRNBERG, K.; SEREGI, J.; HOLLO, I.; REPA, I.; ENDER, K.: Influence of feeding on fattening performance and carcass quality of young Hungarian Grey and Holstein Friesian bulls. Arch. Tierz. 47 (2004), 313-323 [in German]

JORDANA, J.; PIEDRAFITA, J.; CARRE, X.; MARTELL, A.: Conservation genetics of an endangered Catalonian cattle breed ('Alberes'). Genetics and Molecular Biology 22 (1999) 3, 387-394 
KALINOWSKI, S.T.:

Counting alleles with rarefaction: Private alleles and hierarchical sampling designs. Conservation Genetics 5 (2004), 539-543

KATANEN, J.; OLSAKER, I.; HOLM, L.-E.; LIEN, S.; VILKKI, J.; BRUSGAARD, K.; EYTHORSDOTTIR, E.; DANELL, B.; ADALSTEINSSON, S.:

Genetic diversity and population structure of 20 North European cattle breeds. J. Hered. 91 (2000), 446- 457

LUIKART, G.L.; ALLENDORF, F.W.; CORNUET, J.M.; SHERWIN, W.B.:

Distortion of allele frequency distributions provides a test for recent population bottlenecks. J Heredity 89 (1998), 238-247

MACHUGH, D.E.; LOFTUS, R.T.; CUNNINGHAM, P.; BRADLEY, D.G.:

Genetic structure of seven European cattle breeds assessed using 20 microsatellite markers. Animal Genetics 29 (1998), 333-340

MAUDET, C.; LUIKART, G.; TABERLET, P.:

Genetic diversity and assignement tests among seven French cattle breeds based on microsatellite DNA analysis. J. Anim. Sci. 80 (2002), 942-950

MOIOLI, B.; NAPOLITANO, F.; CATILLO, G.:

Genetic diversity between Piedmontese, Maremmana, and Podolica cattle breeds. Journal of Heredity 95 (2004) 3, 250-256

NEI, M.; TAJIMA, F.; TATENO, Y.:

Accuracy of estimated phylogenetic trees from molecular data. J. Mol. Evol. 19 (1983), 153-170

OLDENBROEK, J.K.:

Genebanks and the conservation of farm animal genetic resources. DLO Institute for animal science ÖNGENE: and health, P.O.Box 65, 8200 AB Lelystad, The Netherlands (1999)

Austrian association for rare endangered breeds. Available at http://www.oengene.at (2007)

PIRY, S.; LUIKART, G.; CORNUET, J-M.:

BOTTLENECK - a computer program for detecting recent reductions in the effective population size using allele frequency data. J. Hered. 90 (1999), 502-503

RANNALA, B.; MOUNTAIN, J.L.:

Detecting immigration by using multilocus genotypes. Proc. Natl. Acad. Sci. USA 94 (1997), 91979221

RENDO, F.; IRIONDO, M.; JUGO, B.M.; AGUIRRE, A.; MASON, L.I.; VICARIO, A.;GOMEZ, M.; ESTONBA, A.:

Analysis of the genetic structure of endangered bovine breeds from the Western Pyrenees using DNA microsatellite markers. Biochemical Genetics 42 (2004) 3/4, 99-108

ROSENBERG, N.A.:

DISTRUCT - a program for the graphical display of population structure, Mol. Ecol. Notes 4 (2004), 137-138

SAS:

SAS Version 9.1.3, SAS Institute Inc., Cary, NC, (2003)

TAKEZAKI, N.; NEI, M.:

Genetic distances and reconstruction of phylogenetic trees from microsatellite DNA. Genetics 144 (1996), 389-399

TREXLER, J.C.:

Hierarchical organization of genetic variation in the Sailfin Molly, Poecilia latipinna (Pisces: Poeciliidae). Evolution 42 (1988), 995-1005

WEIR, B.S.; COCKERHAM, C.C.:

Estimating F-statistics for the analysis of population structure. Evolution 38 (1984), 1358-1370

WRIGHT, S.:

The Theory of Gene Frequencies: Evolution and the Genetics of Populations, Vol.2. Chicago University press, Chicago, USA (1969) 
Authors:

SUPAWADEE MANATRINON*

Division of Livestock Sciences

University of Natural Resources and

Applied Life Sciences Vienna

Gregor Mendel Straße 33

A-1180 Vienna

Austria

email:msupawad@su.ac.th

Faculty of Animal Sciences and Agricultural Technology

Silpakorn University

Sampraya, Cha-Am, Phetchaburi 76120

Thailand

Dr.FRANZ FISCHERLEITNER

email: franz.fischerleitner@raumberg-gumpenstein.at

Institute for Organic Farming and Biodiversity

Austraße 10

Postfach 164601 Wels

Vienna

Austria

Dr. ROSWITHA BAUMUNG

email: roswitha.baumung@boku.ac.at

Division of Livestock Sciences

University of Natural Resources and Applied Life Sciences Vienna Gregor Mendel Straße 33

A-1180 Vienna

Austria

*Corresponding author 